\title{
THE GRAMMATICAL SHIFT IN TRANSLATING CAUSATIVE CONSTRUCTION FROM INDONESIAN INTO ENGLISH IN ANDREA HIRATA'S NOVEL "LASKAR PELANGI AND THE RAINBOW TROOPS"
}

\author{
Cucu Mariam ${ }^{\left.a^{*}\right)}$, Lungguh Halira Vonti ${ }^{a)}$ \\ ${ }^{a)}$ Universitas Pakuan, Bogor, Indonesia \\ ${ }^{*}$ Corresponding Author: cucumariam@unpak.ac.id
}

Article history: received 31 January 2020; revised 19 February 2020; accepted 19 February 2020

\begin{abstract}
The purpose of this study is to find causative construction in Indonesian and English in the novel Laskar Pelangi and the translation of The Rainbow Troops by Andrea Hirata, analyse and examine in depth the equivalence and grammatical incompatibility of the translation of the causative construction, and describe the shift in grammatical equivalence of the translation of causative constructs from Indonesian into English. The method used in this study is content analysis with a qualitative approach. This method is used to find facts about grammatical equivalence in the form of causative construction. The shift in the word level occurs at a higher level, namely the phrase, at the phrase level there is no shift, and at the level of the clause, there is a shift at a lower level, namely the phrase or higher level, namely the main clause and sentence. In the sentence level, the shift occurs in the type of sentence, into sentences that are wider or smaller, or into clauses. The novelty in this research is the grammatical equivalence of causative constructs in translation and its shift from Indonesian into English.
\end{abstract}

Keywords: grammatical equivalence; causative construction; shift.

\section{INTRODUCTION}

Translation is the process of transferring the content of the text from one language as an SL to another language or other languages as a TL or TLs. The content translation in the target language must be appropriate with the content of the source language. It is because the aim of the writer and the information given must be able to be accepted by all the readers in all languages. In other words, the readers have the same understanding when they read the text in both languages (SL and TL) if they understand both languages. It is something that must be known by the translators. Based on that, translation needs a person who is good at Linguistics, social and cultural science and also communicative science related to the subject of translation.

Linguistics is one of the knowledge that must be mastered by the translator. It is because Linguistics, inside it is the language, is the main tool in translation. One of the language competences is grammar that is the rule of the language. Every language in the world has its own grammar system. The different grammatical system causes the changes of the content of information or text in translation. To prevent that, the translator adds or omits the information in his translation. It happens in translation if the target language does not have any certain grammatical categories that are equivalent to the source language (Baker in Iqbal [1]. However, sometimes the information is translated in the target language whose meaning is equivalent. the equivalence is needed to overcome the conflict between an extra textual factor and linguistic factor in both SL and TL.

There are several equivalences in translation, one of them is grammatical equivalence, it is very crucial in translation because it manages which form that must be used in translating the text in order that the text translated has the equivalent content and meaning. Iqbal [1] say that it will raise a problem if the grammar in both languages (SL and TL) is not equivalent. According to Baker in Sudirman [2] grammatical equivalence consists of number, gender, person, tenses, active passive construction, direct indirect speech and causative construction.

In order to get the equivalence, in translation the shift or transposition often happens in order that the translated text from SL to TL can be accepted by the readers. The shifts may also happen in translating causative construction found in the novel The Rainbow Troops. The shifts are seen from the point of grammatical view, especially syntactical unit: word, phrase, clause and sentence. To know the translation shift happen in the Indonesian English translated novel, The Rainbow Troops, the question of the research is how the grammatical shift happen in the translation of causative construction from Indonesian into English language in the novel The Rainbow Troops.

Causative Construction

According to Shibatani (1976), Frawley (1992) and Curnow (1993) in Mulyadi [3], causative is a situation consisting of two events, caused event and causing event, reflecting the component of cause and effect. Causative is related to an action or a verb causes something happen. Kridalaksana [4] states the same definition, causative construction is a construction that states, " $\mathrm{X}$ causes $\mathrm{Y}$ and becomes z". For example, Saya menyebabkan dia membaca buku itu 'I make him read the book'. It means that the causative is a verb that states cause and effect that has a 
grammatical relation between caused event and causing event [4]. In other words, coausatives is an event causes another event.

There are three kinds of causatives:

1) Lexical causatives

Lexical causatives is a construction that relates two phenomenon written clearly in one clause using a lexicon showing a cause and effect. For example, I allow him to go, I ask you to go, I made him leave.

2) Morphological causatives

The construction has an affixes and suffixes on its verb, for example Harun telah menyelamatkan kami. The suffix -kan in the verb selamat is the sign of morphological causative construction. This kind of construction are mostly found in Indonesian language.

3) Periphrastic analytical causatives

According to Whaley [5] periphrastic construction is a construction in which multiple verb forms are used to express what can commonly be expressed by a single verb in conjunction with affixes. It means that this construction is based on the meaning of the whole construction or sentence without any affixes, and the cause and effect can be seen directly from the sentence. For examples, (1) Ali menyakitiku. From that example we can see that $A k u$ sakit as a caused event, and $A l i$ membuatku sakit as a causing event. (2) He forced me to do it. It means that because of him, I do something. We can conclude that 'cause' and 'effect' are shown in different verbs. Both Indonesian and English have this construction.

\section{Translation Shift}

Catford in Alzuhdy [6] said that shifts in translation mean changing formal correspondence from SL to TL in order that the translation is acceptable. Formal correspondence is related to the equivalence of linguistic category in two different languages. In morphem and word level the translation is still possible to be equivalent. For example, Budi akan pergi ke sekolah besok 'Budi will go to school tomorrow'. However, most of the time, the changes or shifts happen because the formal correspondence are not the same in SL and TL. That is called translation shift. There are two kinds of translation shift: level shift and category shift.

\section{A) Level shift}

Level shift happens from grammar to lexis or vice versa. It means that from grammar part in one language that must be translated into word in another language. For example, perfective form in English (hav/has + past participle) is translated into word into Indonesian language 'sudah' or 'telah' (Machali in Alzuhdy [6]). John has stopped smoking. 'John sudah berhenti merokok'.

B) Category shift

In translation the shift of forms commonly happen between SL and TL. There are four types of category shift:

1) Structure shift happens because the grammatical arrangement or word arrangement in the sentence changes. It is because of the rules in the language used in translation or because of the styles of the translator. For example: Pabrik mainan (SL) 'toy factory' (TL), Sebelum meninggalkan ruangan, dimatikannya lampu. (SL) 'Before leaving the room, he turned the lamp off' (TL). Ia mengambil bola itu dari dalam kotak (SL) 'The ball was taken out of the box (TL).

2) Class shift happens if the shift in the word classes in one language changes into phrases or another word classes in other languages. For example, adverbs in English are mostly equivalent in phrase for, in Indonesian language, carefully (adverb in English) 'dengan hati-hati' (Phrase in Indonesian language). Mechanical engeenering (adjective) 'teknik mesin' (noun).

3) Unit shift happens if there is a change in the language unit. Machali in Alzuhdy [6] said that every language has some language units: morpheme, word, phrase, clause, sentence, paragraph and text. If the shift of translation happens into the higher one, it is called upward rank shift and if it happens into the lower one, it is called downward rank shift. For example, gravity (English word) 'gaya tarik bumi' (Indonesian phrase). It is upward rank shift.

4) Intra-system shift happens if the grammar of the languages used in translation is different. It is related to the acceptability of the result of the translation.

\section{Translation}

According to House [7], translation is the replacement of an original text with another text. It reduplicates the communicative events for people who are not participating in the original text. Therefore, translation is called a secondary communication. In the same line as House [7] defined translation is as the switch of the message from SL to TL. Ideally the translation in TL has the same message as the message in the SL.

A more detail definition is stated by Wuryantoro in Iqbal [1], translation is a process in which some activities such as learning lexicon, grammar, cultural context in the source language are needed. The message in the TL must be equal in the SL. Another different translation is stated by Bell in Alfaori [8] translation is an abstract concept consisting of a process and a product. The product is the result of the process that must be complete, clear and accurate that is suitable to the goal and purpose of the resource text.

Based on the definition above, it can be concluded that translation is transferring process from SL into TL in the text form in which it has the same content, message, objective and purpose but in different form of word and grammar, despite the translation is acceptable.

\section{Literature Translation}

Novel or fiction is a kind of literature as the result of an art which is creative and imaginative. It is not real but it is based on the real life or the real experience. Therefore, literature translation is a process of translation that is related to culture and social that become the background of the text or the novel. The words used must be different in their meaning, which is more specific. The literature translation is 
specific because the text translated is consisting of the writer's expression, emotion, the beauty of the word or expression and the beauty of sound. In novel it is only the beauty of words chosen that can be felt by the reader.

According to Lustyantie [9], the translation of literature text must be different from the original text . It is because the translated literature text is not part of the origin literature anymore. In other words, it has become the part of the target language. Besides, the translated literature text has been influenced by the translator's language, grammar, culture, social history and geography.

\section{RESEARCH METHODS}

The method used in the study is content analysis with qualitative approach which can give a valid conclusion from the text and its context. The reason of using content analysis is because the data of this study is a literature written text, a novel, written by Andrea Hirata entitled Laskar Pelangi and its translation into English The Rainbow Troops which is translated by Angie Kilbane. Because the analysis used is content analysis, the contents of the two novels that show the causatives are categorized and classified in order to find out the shift of causative translation from Indonesian into English.

\section{RESULTS AND DISCUSSION}

\section{A. The translation shift in the word level}

The data found in word level are as follows:

Table 1. The translation shift in the word level

\begin{tabular}{|l|l|}
\hline \multicolumn{1}{|c|}{ Causatives in Indonesian } & \multicolumn{1}{c|}{ The translation in English } \\
\hline $\begin{array}{l}\text { Tiupan puluhan trombone laksana } \\
\text { sangkakala hari kiamat dan dentuman } \\
\text { timpani menggetarkan dadaku. }\end{array}$ & $\begin{array}{l}\text { The pounding of drums shook } \\
\text { my heart. }\end{array}$ \\
\hline $\begin{array}{l}\text { PN memukimkan orang Sawang di } \\
\text { sebuah rumah panjang yang tersekat- } \\
\text { sekat. }\end{array}$ & $\begin{array}{l}\text { PN placed them in a long } \\
\text { house with partitions. }\end{array}$ \\
\hline
\end{tabular}

Causatives 'menggetarkan' and 'memukimkan' belong to transitive verbs that means 'make my chest shaking' and 'cause sawangan people stay'. Those 'menggetarkan' and 'memukimkan' are the verbs (at the word level) as the predicate in the construction in Indonesia language syntax. However, 'shook' and 'placed' are verb phrase (not word) but they are also as predicate in English.

Table 2. The translation shift in the word level

\begin{tabular}{|l|l|}
\hline \multicolumn{1}{|c|}{ Causatives in Indonesian } & \multicolumn{1}{c|}{ The translation in English } \\
\hline $\begin{array}{l}\text { Benar-benar menjatuhkan mental } \\
\text { lawan. }\end{array}$ & $\begin{array}{l}\text { It was enough to break their } \\
\text { rivals' spirits. }\end{array}$ \\
\hline
\end{tabular}

The verb 'menjatuhkan' 'causes to fall down' is translated into adjective 'enough' and to infinitive 'to break'. The shift is not only the grammatical unit but also its sintactic function, as complement and infinitive clause.

B. The Translation Shift in Phrase Level

Based on the data identified and classified, there is not any unit shift found in the phrase level. All the data in the SL are translated into the same syntactic category in the TL.

\section{The translation Shift in the Clause Level}

Based on the data, there are two kinds of shift in the clause level, class shift and unit shift. the class shift is the shift to the same word classes. Meanwhile the unit shift is the shift of translation to different syntactic categories, upward or donward rank shift.

1) Class shift

Table 3. Translation Shift in the Clause Level

\begin{tabular}{|c|c|}
\hline Causatives in Indonesian & The translation in English \\
\hline $\begin{array}{l}\text {......, waktu mendaftarkan anak } \\
\text { laki-laki satu-satunya itu ke } \\
\text { sekolah Islam Puritan dan miskin } \\
\text { ini. }\end{array}$ & $\begin{array}{l}\text {...., to enroll his only son at } \\
\text { this Islamic school. }\end{array}$ \\
\hline $\begin{array}{l}\text {....., asalkan dirinya dapat } \\
\text { menghindarkan diri dari pelajaran } \\
\text { di kelas. }\end{array}$ & $\begin{array}{l}\text {......., as long as he got out of } \\
\text { class. }\end{array}$ \\
\hline $\begin{array}{l}\text {......karena dewa mata tombak } \\
\text { telah melukai hatinya. }\end{array}$ & $\begin{array}{l}\text {....as if god of spears had } \\
\text { pierced his heart. }\end{array}$ \\
\hline .....untuk meringankan beban itu. & ... how to lighten this burden. \\
\hline
\end{tabular}

'waktu mendaftarkan ....' is a subclause (adverbial clause), and it is translated 'to enroll his only son ...' the translation is infinitive clause. (2) 'asalkan dirinya dapat ...' is adverbial clause of condition, and it is translated 'as long as he got out of class' as a noun clause, (3) 'karena dewa mata tombak telah melukai hatinya' is adverbial clause of reason, and it is translated 'as if god of spears ...' into adverbial clause of comparison, (4) 'untuk meringankan beban itu' is as the adverbial clause of goal, and it is translated into noun clause 'how to lighten ....' the data show that the shift happens from one subclause to another subclause. Thus it is called the class shift.

2) Upward rank shift

Table 4. Translation Shift in The Clause Level

\begin{tabular}{|l|l|}
\hline \multicolumn{1}{|c|}{ Causative in Indonesian } & \multicolumn{1}{c|}{ The translation in English } \\
\hline $\begin{array}{l}\text {......ketika kantor pusat PN Timah } \\
\text { membunyikan sirine, pukul 7 } \\
\text { kurang 10. }\end{array}$ & $\begin{array}{l}\text { The sirine roared from the PN } \\
\text { central office. }\end{array}$ \\
\hline $\begin{array}{l}\text { Tahun ini beliau menginginkan } \\
\text { perubahan dan .... }\end{array}$ & $\begin{array}{l}\text { This year Lintang's father } \\
\text { wanted to break that cycle. }\end{array}$ \\
\hline $\begin{array}{l}\text { Bu Mus berusaha keras } \\
\text { menyembunyikan air mata yang .... }\end{array}$ & $\begin{array}{l}\text { Bu Mus tried hard to hide the } \\
\text { tears in her eyes. }\end{array}$ \\
\hline
\end{tabular}

The data show that the translation of the clauses in SL become sentences in TL. It means that the shift of translation changes in higher level, and it is called upward rank shift.

\section{3) Downward rank shift}

Table 5. Translation Shift in the Clause Level

\begin{tabular}{|l|l|}
\hline \multicolumn{1}{|c|}{ Causative in Indonesian } & The translation in English \\
\hline $\begin{array}{l}\text { Prajurit-prajurit itu menyelamatkan } \\
\text { para sapid an berkelahi .... }\end{array}$ & ....to save the cows. \\
\hline $\begin{array}{l}\text {....yang telah menyembuhkannya } \\
\text { dari penyakit kudis. }\end{array}$ & ......for curing scabies. \\
\hline
\end{tabular}


The data show that the translation shift happen from the high level to the lower level, from the main clause 'prajurit-prajurit itu...' is translated into infinitive clause '.....to save the cows', and from adjective clause '......yang telah menyembuhkannya....' is translated into prepositional phrase '...... for curing scabies.'

\section{The shift in the Sentence Level}

In the sentence level the shift happens in upward rank shift and downward rank shift.

1) Upward rank shift

Table 6. Translation Shift in the Sentence Level

\begin{tabular}{|l|l|}
\hline \multicolumn{1}{|c|}{ Causatives in Indonesian } & \multicolumn{1}{c|}{ The translation in English } \\
\hline $\begin{array}{l}\text { Merajai lomba kecerdasan, } \\
\text { melejitkan kepercayaan diri kami. }\end{array}$ & $\begin{array}{l}\text { When he'd reigned as king of the } \\
\text { Academic challenge, making our } \\
\text { confidence soar. }\end{array}$ \\
\hline $\begin{array}{l}\text { Aku melepaskan empat tas yang } \\
\text { membebaniku tapi hanya sempat } \\
\text { melambaikan tangan. Ia pun pergi } \\
\text { meninggalkan debu. }\end{array}$ & $\begin{array}{l}\text { I released the four bags slung } \\
\text { over my shoulders but got only } \\
\text { the chance to wave my hand. I } \\
\text { was left waving to dust as he } \\
\text { drove away. }\end{array}$ \\
\hline
\end{tabular}

The first sentence in SL 'merajai lomba...' is a compound sentence, and it is translated into English become the complex sentence 'when he'd reigned ....' The second sentence in SL 'Aku melepaskan empat tas ...' is a causative construction in complex sentence and simple sentence, but the sentences are translated into English in compound complex sentence and complex sentence 'I released the four bags ....'

\section{2) Downward rank shift}

In Table 7 show that the shift happens to the lower level. The first data is in complex sentence in SL 'Jabatan itu menyebalkan ...' but it is translated into two sentences, a simple sentence and a compound sentence 'Being class president was not ...' For the second data, the causative construction is in complex sentence in SL 'guru manapun yang membayangkan ...' and it is translated into compound sentence in TL 'One look at his face and any teacher would feel ....'

Table 7. Translation Shift in the Sentence Level

\begin{tabular}{|l|l|}
\hline \multicolumn{1}{|c|}{ Causative in Indonesian } & \multicolumn{1}{c|}{ The translation in English } \\
\hline $\begin{array}{l}\text { Jabatan itu menyebalkan antara } \\
\text { lain karena harus mengingatkan } \\
\text { anggota kelas agar jangan berisik } \\
\text { padahal diri sendiri tidak bisa } \\
\text { diam. }\end{array}$ & $\begin{array}{l}\text { Being class president was not a } \\
\text { pleasant position. He was supposed } \\
\text { to keep us quiet, but he himself } \\
\text { could not shut up. }\end{array}$ \\
\hline $\begin{array}{l}\text { Guru manapun yang } \\
\text { membayangkan wajahnya akan } \\
\text { tertekan jiwanya, membayangkan } \\
\text { betapa susahnya menjejalkan ilmu } \\
\text { ke dalam kepala aluminiumnya. }\end{array}$ & $\begin{array}{l}\text { One look at his face and any } \\
\text { teacher would feel depressed } \\
\text { imagining the difficulty of } \\
\text { cramming knowledge into his } \\
\text { head. }\end{array}$ \\
\hline
\end{tabular}

\section{CONCLUSION}

The shift in translation in causative construction based on its syntactic categories, word and sentence happen in upward rank shift and downward rank shift. Meanwhile in the clause level it happens in upward rank shift, downward rank shift and class shift.

\section{REFERENCES}

[1] Iqbal, Rachmad, Potjut Ernawati, and Ika Apriani Fata. 2016. Equating Grammatical Equivalence of College Students. Banda Aceh: University of Syiah Kuala.

[2] Sudirman, Anselmus. 2016. Current Issues in EnglishIndonesia Translation Equivalences. International Journal of Science and Research (IJSR).

[3] Mulyadi. 2004. Konstruksi Kausatif dalam Bahasa Indonesia. Linguistika.

[4] Kridalaksana, Harimurti. 2009. Kamus Linguistik. Jakarta: Gramedia

[5] Whaley, J., Lindsay. 1997. Introduction to Typology: The Unity and Diversity of Language. NewDelhi: Sage Publications.

[6] Alzuhdy, Abduh Yosa. 2019. Analisis Translation Shift dalam Penerjemahan Bilingual Bahasa Inggris-Bahasa Indonesia. Academia Edu.

[7] House, Juliane. 2009. Translation. Oxford: Oxford University Press.

[8] Alfaori, Mosleh Daoud Ahmad. 2017. Equivalence Problems in Translation. Sino-US English Teaching.

[9] Lustyantie, Ninuk. Peranan Bahasa Indonesia dalam Karya Terjemahan. Jurnal Bahasa Sastra dan Pembelajarannya. Vol. 2 No. 2 Gorontalo: Penerbit Universitas Gorontalo. 